\title{
Presence of IS/1494/06 genotype-related infectious bronchitis virus in breeder and broiler flocks in Turkey
}

\author{
Serpil KAHYA ${ }^{1}$, Fethiye COVEN ${ }^{2}$, Seran TEMELLI ${ }^{3}$, Aysegul EYIGOR ${ }^{3}$, Kamil Tayfun CARLI $^{1}$ \\ ${ }^{1}$ Department of Microbiology, ${ }^{3}$ Department of Food Hygiene and Technology Faculty of Veterinary Medicine, 16059 Bursa, \\ ${ }^{2}$ Bornova Veterinary Control Institute, 35010 Izmir/Turkey.
}

\begin{abstract}
Summary: In this study, infectious bronchitis (IB)-suspect problems were observed in 2 broiler and 8 breeder chicken flocks vaccinated with H120 strain, and a total of 220 tracheal swabs were taken from 60 broiler chickens of 2 flocks ( 30 swabs/flock), and 160 breeder chickens of 8 flocks (20 swabs/flock) to detect infectious bronchitis virus (IBV) by a reverse transcriptase polymerase chain reaction (RT-PCR) and to isolate IBV from chickens showing respiratory sings and nephritis lesions. Detection of 8 Turkish IBVs from the tracheal swab samples directly by RT-PCR was confirmed by both IBV isolation from allantoic fluids of embryonated eggs and by the same RT-PCRs from these samples. Basic Local Alignment Search Tool (BLAST) results revealed that all 8 sequences from our Turkish IBV isolates were related to that of EU780077 (IS/1494/06 IBV strain) with a 99\% identity. Phylogenetic and alignment analyses of the sequences of two representative isolates as TR_IS1494_06_B12011 from one broiler flock and TR_1494_06_7201 from one breeder flock also confirmed this close relation to IS/1494/06 IBV genotype. As a result, Turkish IBVs have been isolated for the first time from chickens, which were not protected from IB despite IBV H120 strain vaccination, and genotyped as IS/1494/06 in Turkey suggesting the transfer of this IBV from the countries of Middle East.
\end{abstract}

Key words: IS/1494/06 Infectious bronchitis virus, chicken, Turkey

\section{Türkiye’de damızlık ve broyler sürülerde IS/1494/06 genotipi-ilişkili infeksiyöz bronşit virusunun varlığ}

Özet: Bu çalışmada H120 suşu ile aşılanmış 2 broyler ve 8 damızlık sürüde infeksiyöz bronşit şüpheli problemlere rastlanmış 2 sürüye ait 60 broyler tavuktan (30 svap/sürü) ve 8 sürüye ait 160 damıllık tavuktan (20 svap/sürü) özellikle solunum bulguları ile nefrit lezyonları gösterenlerden toplam 220 trakeal svap infeksiyöz bronşit virusu (IBV)'nu reverse transcriptase polymerase chain reaction (RT-PCR) ile belirlemek ve IBV'yi izole etmek amacı ile alındı. IBV'nin trakeal svap örneklerinden direkt olarak RT-PCR ile deteksiyonu embryolu yumurtaların allantoik sıvılarından IBV izolasyonu ve bu örneklerden RT-PCR yapılması ile doğrulandı. Basic Local Alignment Search Tool (BLAST) sonuçları 8 Türk izolatının EU780077 (IS/1494/06 IBV suşu) ile \%99 benzerlik gösterdiğini ortaya koydu. Broyler sürüden TR_IS1494_06_B12011 ve damılik sürüden TR_1494_06_7201 olarak seçilen temsili iki izolatın dizilerinin filogenetik ve sıralama analizleri de IS/1494/06 IBV genotipine yakınlığ $\bar{g}_{1}$ doğruladı. Sonuç olarak, Türkiye'de IBV H120 suşu ile aş1lamaya rağmen IB'den korunamayan tavuklardan ilk defa izole edilmesi ve IS/1494/06 olarak genotiplendirilmesi bu IBV'nin Orta Doğu ülkelerinden taşınma olasılığını akla getirmektedir.

Anahtar sözcükler: IS/1494/06 İnfeksiyöz bronşit virusu, tavuk, Türkiye

\section{Introduction}

Avian infectious bronchitis (IB) is an extremely contagious disease encountered in the commercial poultry industry resulting substantial economic losses. The disease symptoms and related lesions are most frequently observed in the respiratory, reproductive and renal systems of broilers and egg-type chickens $(6,9)$. IB is caused by infectious bronchitis virus (IBV), which belongs to the Coronavirus genus in the Coronaviridae family (5). The virus is enveloped, and has a positivesense, single-stranded, approximately $27 \mathrm{~kb}$ ribosomal nucleic acid (RNA) genome encoding three major structural proteins: the nucleocapsid protein, the membrane protein, and the spike (S) glycoprotein. The S1 subunit of S glycoprotein located outside of the virus plays a role for the fusion between the virus envelope and the host cell membrane (3). The epitopes in this subunit are protective antigens, and are responsible for the production of neutralizing antibodies (2). In the S1 subunit, there are some hypervariable regions (HVR) determining the genotypes and serotypes, which are identified by molecular analyses of these regions (10). Today there are many IBV serotypes or genotypes due to point or recombination mutation-related variations in the 
HVRs of IBVs $(4,7,8,11,12)$. Therefore, as a consequence of these variations, protection against IB by vaccination with standard vaccine strains can be inefficient.

There are still many IB-suspect outbreaks occurring in Turkey despite vaccinations against IB with strains such as Connecticut, H120, Ma5 and M41. In these outbreaks, the diagnoses have remained questionable due to lack of confirmation by virus isolation and characterization of the isolate, which solely based on clinical and serological data evaluation. Related to this, in this work, we examined IB-suspect breeder and broiler flocks in the East Anatolian Region of Turkey with respiratory problems and nephritis, which had previously been immunized by a vaccine including the H120 strain, and we isolated IS/1494/06-related IB viruses from tracheal swabs of these birds, and performed their phylogenetic analyses.

\section{Materials and Methods}

Samples: In August 2011, respiratory problems such as gasping, sneezing and bronchial rales, and nephritis lesions such as enlargement, congestion and urolithiasis in kidneys were notified in the $30 \mathrm{~d}$ old broilers, while 40-50 wk old breeders had only respiratory signs. Both types of chickens were Ross 308 breed, and had regularly been vaccinated with IBV H120 strain in a poultry company located in the city of Malatya in the East Anatolian Region of Turkey. A total of 220 tracheal swabs taken from 160 breeder chickens of 8 flocks (20 swabs/flock), and 60 broiler chickens of 2 flocks (30 swabs/flock) were individually placed into sterile tubes containing $10000 \mathrm{IU} / \mathrm{ml}$ penicillin, $10 \mathrm{mg} / \mathrm{ml}$ streptomycin and $25 \mu \mathrm{g} / \mathrm{ml}$ amphotericin B (SigmaAldrich, A5955) in tryptose phosphate broth (Becton Dickinson, 260300), $\mathrm{pH} 7.0$ to 7.2 , and were submitted to our laboratory in dry ice within $18 \mathrm{~h}$ of collection. Four or five swabs were pooled and treated as one sample in RNA isolation (Table 1).

Table 1. Sample information and IBV RT-PCR results. Tablo 1. Örnek bilgileri ve IBV RT-PCR sonuçları.

\begin{tabular}{|c|c|c|c|}
\hline \multirow[t]{2}{*}{ Flock ID } & \multirow{2}{*}{$\begin{array}{l}\text { Number of } \\
\text { tracheal swabs - } \\
\text { total/pooled }\end{array}$} & \multicolumn{2}{|c|}{ IBV RT-PCR results with } \\
\hline & & $\begin{array}{c}\text { tracheal } \\
\text { swabs }\end{array}$ & $\begin{array}{l}\text { allantoic } \\
\text { fluid }\end{array}$ \\
\hline Broiler 1 & $30 / 7$ & + & + \\
\hline Broiler 3 & $30 / 7$ & + & + \\
\hline Breeder 7 & $20 / 5$ & + & + \\
\hline Breeder 8 & $20 / 5$ & + & + \\
\hline Breeder 9 & $20 / 5$ & - & - \\
\hline Breeder 12 & $20 / 5$ & - & - \\
\hline Breeder 13 & $20 / 5$ & + & + \\
\hline Breeder 14 & $20 / 5$ & + & + \\
\hline Breeder 15 & $20 / 5$ & + & + \\
\hline Breeder 16 & $20 / 5$ & + & + \\
\hline
\end{tabular}

RNA extraction: Total RNA was extracted directly from the pooled tracheal swab sample suspensions and from the allantoic fluid of embryonated chicken eggs used for virus isolation by using Nucleic Acid Extraction Kit (QIAamp MinElute Virus Spin, 57704) following the manufacturer's instructions.

Detection of IBV genome from the samples: Viral RNA was screened for the presence of IBV by using a nested RT-PCR according to Pouhang et al. (15). The reaction was performed with QuantiTect Probe RT-PCR Kit (QIAGEN, 204445). The first amplification reaction was carried out with one-step RT-PCR using the primer sets of FOR1 (5'-CTT TTG TTT GCA CTA TGT AG-3') and RE3 ( $5^{\prime}$-TAA TAA CCA CTC TGA GCT GT-3'). The second amplification reaction was carried out using the primer sets of FOR2 (5'-CAG TGT TTG TCA CAC ATT GT-3') and RE2 (5'-CCA TCT GAA AAA TTG CCA GT-3 ${ }^{\prime}$ ). Amplification products were analyzed in $1.5 \%$ agarose gel. The predicted size of nested RT-PCR product was about 400-bp as described in Pouhang et al. (15).

Virus isolation and propagation: The supernatant of each IBV-positive sample determined by RT-PCR was inoculated into five 11-day-old embryonated chicken eggs. The eggs were inoculated with $0.2 \mathrm{ml}$ of the sample into the allantoic cavity, incubated at $37^{\circ} \mathrm{C}$ and examined daily. All allantoic fluids were harvested at $96 \mathrm{~h}$ post inoculation, and stored at $-70^{\circ} \mathrm{C}$. Three further blind serial passages were performed in a similar way (14).

Genotype identification by sequencing and phylogenetic analysis: The RT-PCR products were cut from the gel and purified using the GeneJET Gel Extraction and PCR purification kits (Fermentas Inc., Ontario, Canada) according to the manufacturer's protocol. Purified RT-PCR products were sequenced in a forward direction using primer FOR1 and in a reverse direction using primer RE3. Sequencing reactions were performed with the ABI Prism BigDye Terminator Cycle Sequencing Ready Reaction Kit (Applied Biosystems, USA) as described by the manufacturer in an ABI Prism 310 Genetic Analyzer (Applied Biosystems, USA). To genotype the Turkish IBV isolates, amplified S1 gene sequence regions of the isolates were compared with the IBV sequences in GenBank database using a BLAST search via the National Center of Biotechnology Information (USA), and sequence similarities by BLAST analysis were included in alignment and phylogenetic construction. The phylogenetic tree was constructed by Unweighted Pair Group Method using Arithmetic averages (UPGMA) together with a bootstrap analysis. The analysis was carried out in CLC Sequence Viewer version 6.6.1. The amplified part of the $\mathrm{S} 1$ gene sequence of the IBV isolate was submitted to the GenBank database. The S1 gene sequences belonging to other 

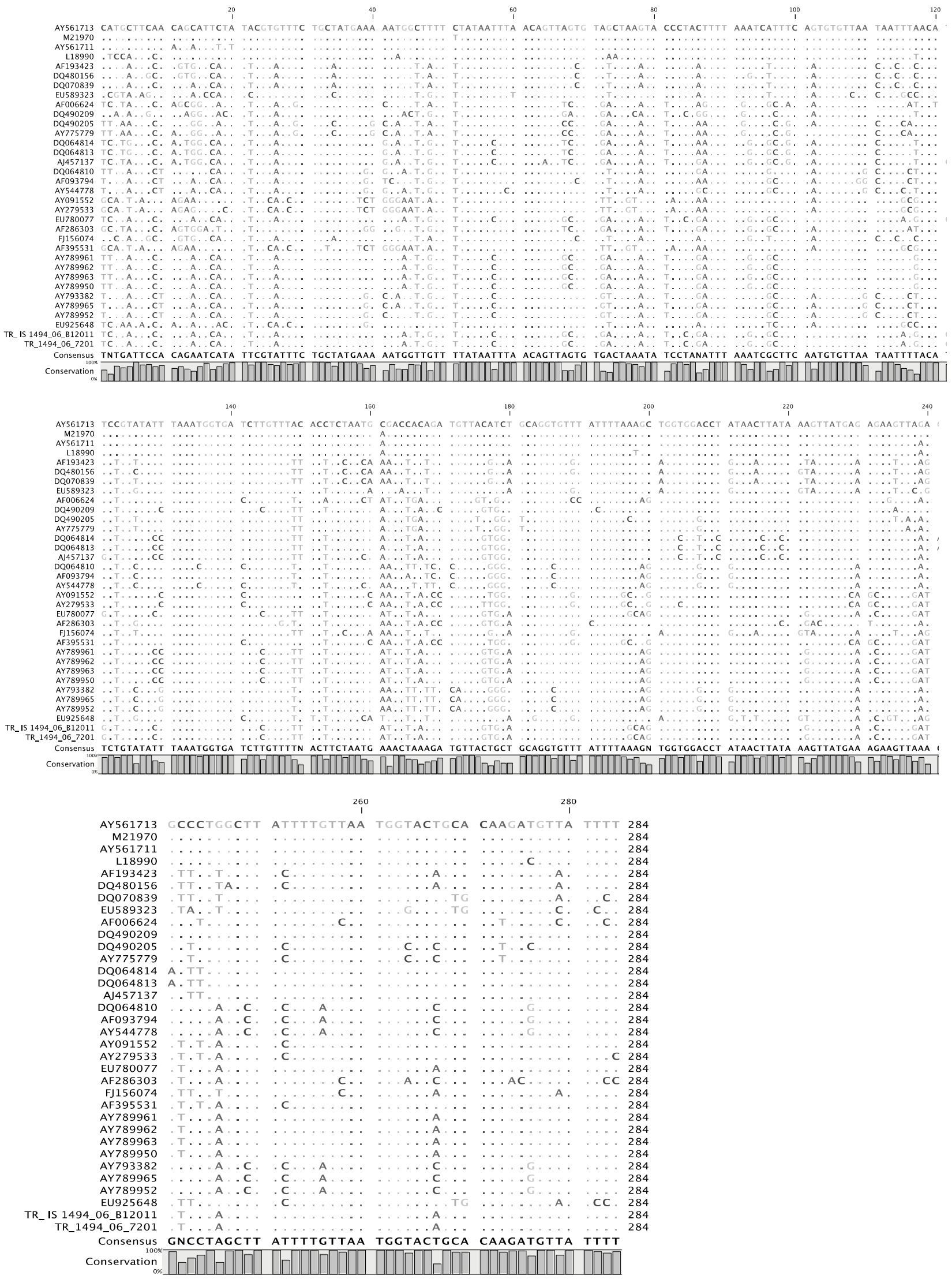

Figure 1. The nucleotide alignments of the amplified HVR sequences of the S1 gene of the Turkish isolates compared with the IBV sequences in GenBank database. Dots indicate nucleotides identical to that of AY561713 (Ma5 strain). The sequences seem to be identical in both Turkish isolates and in the EU780077 (IS/1494/06 strain).

Şekil 1. Amplifiye edilen Türkiye izolatlarının nükleotid dizileri ile GenBank veritabanında bulunan IBV dizilerinin karşılaştırılmalı sıralanmaları. Noktalar AY561713 (Ma5 suşu) ile identikalliği göstermektedir. Diziler her iki Türk izolatında ve EU780077 (IS/1494/06 strain)'de aynı gözükmektedir. 
previously deposited in the GenBank database were used for comparison and alignment in this study are: M41 (AY561711), Ma5 (AY561713), H120 (M21970), Connecticut 46 (L18990), Spain/00/337 (DQ064813), J2 (AF286303), BJQ (DQ070839), QXIBV (AF193423), SH (DQ480156), 4/91 (AF093794), Australian T (AY775779), Armidale (DQ490205), DLD (EU589323), Egypt/Beni-Seuf/01 (AF395531), Israel/720/99 (AY091552), IS885 (AY279533), THA30151 (FJ156074), THA40151 (EU925648), IS/1494/06 (EU780077), $\quad$ IS/223/96 (AY789950), IS/589/98 (AY789963), IS/585/98 (AY789962), IS/572/98 (AY789961), Q1-73 (DQ490209), Spain/00/338 (DQ064814), Italy-02 (2007) (AJ457137), Ark DPI (AF006624), IS/640714/96 (AY789965), IS/222/96 (AY793382), IS/251/96 (AY789952), IR1061-PH (AY544778), Spain/99/319 (DQ064810).

Accession number for the reported sequence: The amplified part of the S1 gene sequence of the IBV isolate was submitted to the GenBank database and has being in the process of Genbank accession number assignment.

\section{Results}

Virus detection: Pooled tracheal swab samples from IB-suspect 2 broiler and 8 breeder flocks were screened, and except 2 breeder flocks, all were determined to be positive by nested RT-PCR. The allantoic fluid from the third passage of each sample in the embryonated eggs was also tested by the same RT-PCR for the identification of the virus; thereby isolation of 8 Turkish IBVs from the above IBV positive tracheal samples was confirmed (Table 1).

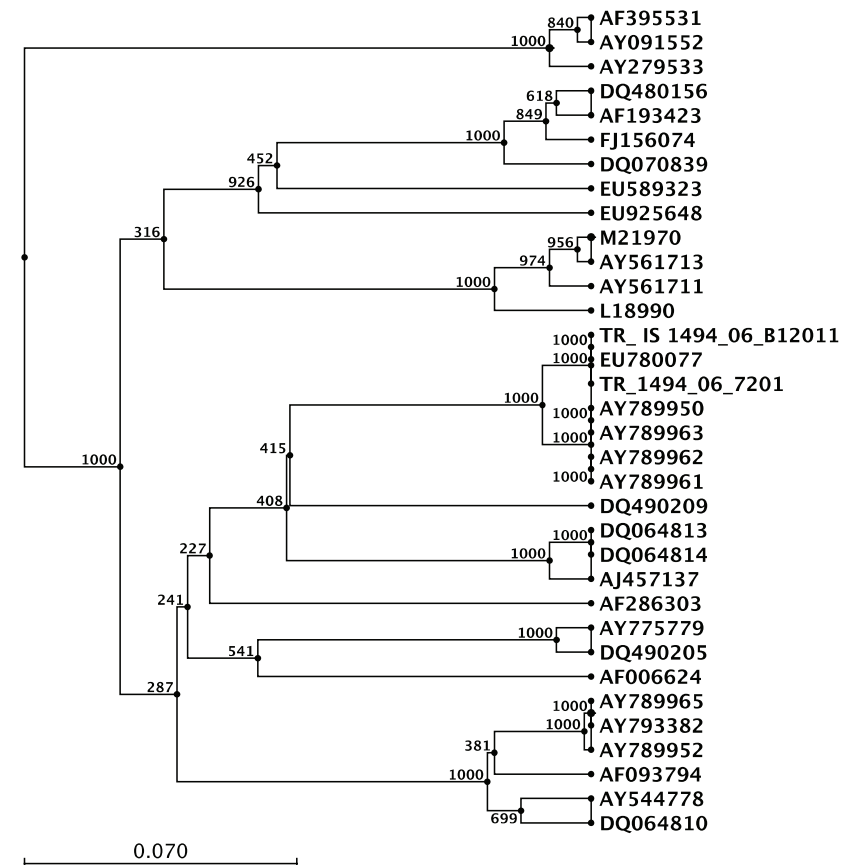

Figure 2. Phylogenetic tree based on the nucleotide sequence between aligned $\mathrm{S} 1$ sequences from the Turkish IBV isolates and published sequences.

Şekil 2. Türkiye IBV izolatlarının ve yayınlanmış dizilerin sıralanmış S1 dizilerinin filogenetik ağacı.
Genotyping and phylogenetic analysis: The nucleotide alignments of the amplified HVR sequences of the $\mathrm{S} 1$ gene of the 8 Turkish isolates were compared with the IBV sequences in GenBank database using a BLAST search via the National Center of Biotechnology Information (USA). BLAST report results revealed that all 8 sequences from our Turkish IBV isolates were related to that of EU780077 (IS/1494/06 IBV strain) with an identity of $99 \%$. All 8 sequences were found identical; therefore 2 representative sequences (one from one IBV isolate from Broiler flock - TR_IS1494_06_B12011, and other from one of the Breeder flock TR_1494_06_7201) were selected and used in multiple sequence alignment (Figure 1) of the amplified region of the $\mathrm{S} 1$ gene. The phylogenetic tree constructed from the nucleotide sequences of the 2 representative IBV isolates and their genetic relationship to the other 32 IBV strains is represented in Figure 2.

\section{Discussion and Conclusion}

Currently, Ma5 and H120 IBV-based vaccination strategies have been applied for the control of IB in chickens in Turkey. In addition to these two vaccine strains, another strain called 4/91 has also been given permission for vaccination. However, there have been persistence in problems related to IB-suspect cases in spite of the use of these three vaccine strains. One of such IB-related problems has occurred in broiler and breeder flocks with a proper H120-based IB vaccination in a poultry company located in the city of Malatya in East Anatolian region of Turkey in August 2011. Thereupon, tracheal swab samples were taken from the broilers with tracheal rales, gasping, coughing, sneezing, nephritis lesions, and from breeders with the same respiratory problems in the same poultry company for IBV isolation and genotyping.

IBV identification and genotyping was performed by the detection and analysis of a region in the HVR of the S1 gene as indicated by Pohuang et al. (15). Two and 6 IBVs were directly detected from the tracheal swabs of 2 broiler and 8 breeder flocks, respectively by IBV RTPCR. Then these IBVs from the same tracheal swabs of the same flocks were isolated in chicken embryonated eggs, and the viruses were identified by the same RTPCR (Table 1). This indicated that the methodology described by Pohuang et al. (15) performed equally well in detecting IBVs directly from the tracheal swabs and from the allantoic fluids of embryonated eggs for the virus isolation.

In this study, both $\mathrm{S} 1$ gene comparison and phylogenetic analyses of the 400-bp product amplified in IBV RT-PCR showed that all broiler and breeder IBV isolates were $99 \%$ identical to the nephropathogenic IS/1494/06 IBV strain, and that these Turkish IBV isolates had distant relation to vaccine strains (H120, Ma5 and 4/91) currently used in Turkey (Figures 1 and 
2). The isolation of IS/1494/06 IBV, one of the Israeli Variant 2 isolates, and information on its S1 gene sequence in GenBank (GenBank Accesion number: EU780077) had first been reported by Meier \& Mahar (2006) from Israel. The IS/1494/06 IBV is still a major variant involved in IBV infections in Israel, and possibly in Jordan and Egypt, and other countries in the Middle East (personal communication, Meier, R. 2012). There is also a report, indicating the persistence of this Israeli Variant 2 isolate (IS/1494/06) - related problems in Egypt in spite of vaccinations of the broiler flocks with H120, which supports the argument of IS/1494/06 IBV presence in the Middle East countries. Also a nephropathogenic IBV related problem other than IS/1494/06 IBV has been reported in Iraq as a neighbouring country to Turkey (13) showing that there can possibly be some other IBV genotypes circulating in the Middle East region countries.

From epidemiological perspective, the isolation of an IBV genotype for the first time in IB-suspect broiler and breeder flocks from the East Anatolian region of Turkey, and the distinctive dissimilarity between our Turkish isolate and the European and the Far Eastern IBVs (Figures 1 and 2), and the homogeneity determined with the IS/1494/06 IBV isolates of the neighboring countries does not seem to be a sole coincidence. Although there is no information currently available how the IS/1494/06 IBV was introduced to Turkey, and how it disseminated among the countries of the Middle East, one possible source of introduction can be the wild birds based on the evidence that IBV may replicate in Anseriformes (1). In addition to this, both the Middle East countries and Turkey has intense trade and uncontrolled movement of inhabitants and animal trade through borders, which may cause clonal dissemination of an IS/1494/06 IBV strain in Turkey and in the neighbouring countries. Elucidation of the current clonal dissemination of this IS/1494/06 IBV strain, and determination of the presence of other possible IBV strains in Turkey is currently an on going research in our laboratory.

As a conclusion, Turkish IBVs have been isolated for the first time from chickens showing IB-suspect symptoms and lesions, and genotyped as IS/1494/06 in Turkey.

\section{Acknowledgement}

This work was supported by the Scientific and Technical Research Council of Turkey Grant No. 1100914.

\section{References}

1. Bochkov YA, Batchenko GV, Shcherbakova LO, Borisov AV, Drygin VV (2006): Molecular epizootiology of avian infectious bronchitis in Russia. Avian Pathol, 35, 379-393.
2. Boursnell MEG, Brown TDK, Foulds IJ, Green PF, Tomley FM, Binns MM (1987): Completion of the sequence of the genome of the coronavirus avian infectious bronchitis virus. J Gen Virol, 68, 57-77.

3. Cavanagh D, Davis PJ, Pappin DJ, Binns MM, Boursnell ME, Brown TD (1986): Coronavirus IBV: partial amino terminal sequencing of spike polypeptide $S 2$ identifies the sequence Arg-Arg-Phe-Arg-Arg at the cleavage site of the spike precursor propolypeptide of IBV strains Beaudette and M41. Virus Res, 4, 133-143.

4. Cavanagh D, Davis PJ, Cook J (1992): Infectious bronchitis virus: evidence for recombination within the Massachusetts serotype. Avian Pathology, 21, 401-408.

5. Cavanagh D (1997): Nidovirales: A new order comprising Coronoviridae and Arteriviridae. Arch Virol, 142,629633.

6. Cook JKA, Jackwood M, Jones RC (2012): The long view: 40 years of infectious bronchitis research. Avian Pathol, 41, 239-250.

7. De Wit JJ, Cook JKA, van der Heijden HMJF (2011): Infectious bronchitis virus variants: a review of the history, current situation and control measures. Avian Pathol, 40, 223-235.

8. Gelb J, Weisman Y, Ladman BS, Meir R (2005): S1 gene characteristics and efficacy of vaccination against infectious bronchitis virus field isolates from the United States and Israel (1996 to 2000). Avian Pathol, 34, 194203.

9. Ignjatovic J, Sapats S (2000): Avian infectious bronchitis virus. The OIE Scientific and Technical Review, 19, 493508.

10. Kingham BF, Keeler CL Jr, Nix WA, Ladman BS, Gelb J Jr (2000): Identification of avian infectious bronchitis virus by direct automated cycle sequencing of the S-1 gene. Avian Dis, 44,325-335.

11. Kottier SA, Cavanagh D, Britton P (1995): Experimental evidence of recombination in coronavirus infectious bronchitis virus. Virology, 213, 569-580.

12. Lee CW, Jackwood MW (2000): Evidence of genetic diversity generated by recombination among avian coronovirus IBV. Arch Virol, 145, 2135-2148.

13. Mahmood ZH, Sleman RR Uthman AU (2011): Isolation and molecular characterization of Sul/01/09 avian infectious bronchitis virus, indicates the emergence of a new genotype in the Middle East. Vet Microbiol, 150, 21-27.

14. OIE Terrestrial Manual 2008. Chapter 2.3.2. (2008): Avian Infectious Bronchitis. pp. 443-455.

15. Pohuang T, Chansiripornchai N, Tawatsin A, Sasipreeyajan J (2009): Detection and molecular characterization of infectious bronchitis virus isolated from recent outbreaks in broiler flocks in Thailand. J Vet Sci 10, 219-223.

Geliş tarihi: 09.08.2012 / Kabul tarihi: 23.10.2012

\author{
Address for correspondence: \\ Dr. Kamil Tayfun Carli \\ Department of Microbiology, \\ Faculty of Veterinary Medicine \\ Uludag University 16059, Görükle Campus, Bursa, Turkey \\ Email:tayfun@uludag.edu.tr
}

